\title{
СОЦИОЛОТИЧЕСКИЕ HAУRИ
}

\author{
НАЦПРОЕКТЫ И РЕАЛИЗАЦИЯ ПРИОРИТЕТНЫХ НАПРАВЛЕНИЙ ГМП В РФ
}

DOI: $10.31618 /$ ESU.2413-9335.2020.6.72.656

Соколовская С.A.

\section{АННОТАЦИЯ}

В данной статье рассматривается один из федеральных проектов, который обозначен как нацпроект «Малое и среднее предпринимательство и поддержка индивидуальной предпринимательской инициативы». Это делается с целью синхронизировать реализацию приоритетных задач ГМП в РФ, а создание условий для реализации потенциала молодёжи в социально-экономической сфере и внедрение технологии «социального лифта» является одной из таких задач, с осуществлением важнейших сдвигов в социально-экономической сфере российского государства.

Ключевые слова: нацпроект, паспорт нацпроекта, приоритетные задачи ГМП, молодёжь

Цели и задачи устойчивого развития страны на основе успешного осуществления нацпроектов определяют, в том числе, основные направления реализации ГМП. Государство и общество должны создать базовые условия для полноценной самореализации молодёжи в социальноэкономической и общественно-политической сферах. Главным результатом реализации приоритетных направлений ГМП в РФ должно стать улучшение социально-экономического положения молодёжи. Одним из индикаторов такого улучшения может служить высокая степень вовлеченности молодёжи в реализацию нацпроектов.

Нацпроекты 2019-2024 - новые национальные проекты федерального масштаба, принятые в 2018 году и разработанные по трём направлениям: «Человеческий капитал», «Комфортная среда для жизни», «Экономический рост». 7 мая 2018 года Президент России В.В.Путин подписал указ «О национальных целях и стратегических задачах развития РФ на период до 2024 года», утверждающий национальные проекты России.

«Национальные проекты построены вокруг человека ради достижения нового качества жизни всех поколений россиян. Высокое качество жизни может быть обеспечено только при динамическом развитии России.»[3]

Нацпроект можно охарактеризовать так:

Общенациональный масштаб

Стратегическая ориентация

Установление новых отраслей как двигателей роста

Нацпроект - это комплексная программа мероприятий, направленная на стабилизацию положения в той или иной сфере жизнедеятельности нации, с персональной ответственностью руководителя и куратора нацпроекта. Всего насчитывается 13 проектов по трём выше обозначенным направлениям. Каждый проект имеет свой паспорт, другими словами, программу действий, которая включает в себя основные положения, цели, целевые и дополнительные показатели, задачи и результаты. Каждый нацпроект разбит на временные этапы с указанием срока завершения. Как правило, это 31 декабря 2024 года.
В данной статье мы обращаемся к одному из проектов, который обозначен как нацпроект «Малое и среднее предпринимательство и поддержка индивидуальной предпринимательской инициативы». Это делается с целью синхронизировать реализацию приоритетных задач ГМП в РФ, а создание условий для реализации потенциала молодёжи в социально-экономической сфере и внедрение технологии «социального лифта» является одной из таких задач[1], с осуществлением важнейших сдвигов в социальноэкономической сфере российского государства.

Нацпроект «МСП» имеет несколько определяющих целей в сфере развития предпринимательской деятельности: улучшение условий ведения предпринимательской деятельности;

- расширение доступа МСП к льготному кредитованию;

- акселерация субъектов МСП;

- поддержка фермерских хозяйств;

- популяризация предпринимательства.

К 2024 году планируется освободить от обязательного предоставления налоговой декларации не менее 1,2 млн. субъектов МСП. А также снять ряд административных ограничений в сфере предпринимательской деятельности. Планируется предоставить доступ к государственной и муниципальной собственности не менее 66 тысяч объектов МСП. К 20 декабрю 2020 года планируется увеличить долю закупок крупными государственными компаниями продукции МСП на 18 процентов, что в свою очередь потребует увеличение доли МСП в системе госзакупок и, разумеется, числа потенциальных участников, поставщиков работ и услуг, из числа малых и средних, и даже микро предприятий. Общий объём закупок крупных заказчиков должен составить в 2024 году 5 трлн. рублей. Особое внимание будет уделяться становлению малых и средних предприятий в сфере производства. Как известно, мелкий частный бизнес хорошо и прочно освоился в сфере услуг и мелкой торговли. Нынешний этап развития нашей страны требует значительного увеличения малых и средних предприятий в сфере производства. Доля таких предприятий должна будет составить 69 процентов 
от общего числа МСП. Притом, что к 1 марта 2024 года должно появиться не менее 60 тысяч новых субъектов предпринимательства. Численность занятых в сфере малого и среднего предпринимательства, включая индивидуальных предпринимателей, должна возрасти с 19,2 млн. человек в 2018 году до 25 млн. в 2024 году. А доля МСП в ВВП страны вырасти с 22,3 процентов в 2017 году до 32,5 процентов в 2024 году.

Решение таких масштабных задач невозможно без активной популяризации малого и среднего предпринимательства, что и нашло отражение в подпроекте «Популяризация предпринимательства».

К сожалению, во время советского периода истории нашей страны частная инициатива не поддерживалась и даже преследовалась, в том числе и в уголовном порядке. Зажиточное крестьянство, по сути дела - успешные фермеры, было ликвидировано в ходе коллективизации как класс. Велась активная контрпропаганда против мелкого предпринимательства. Всё это оставило глубокий болезненный след в сознании российских граждан. Новые поколения советских людей воспринимали частников в негативном свете, как спекулянтов и стяжателей. Теперь настал момент повернуть историю вспять - вернуть доброе имя тем, кто на свой страх и риск открывает предприятия и пытается производить востребованные в обществе услуги, работы и товары. В 2019 году были проведены социологические исследования, выявившие наиболее значимые факторы, которые мотивируют граждан к осуществлению предпринимательской деятельности. Важнейший из них - экономическая самостоятельность, возможность работать на себя, а не на дядю. Но одной мотивации для успешного ведения бизнеса недостаточно. Бизнес - это сфера экономической неопределённости, экономического риска, отсутствие гарантированного успеха. Бизнес требует наличия предприимчивости, оборотистости, делового чутья. Помимо этого занятия бизнесом требуют наличия ряда профессиональных компетенций, которые возможно получить только через систему специализированного образования. Но возможен и другой способ - через систему консультационных центров. Вот почему подпроект «Популяризация предпринимательства» включает в себя развитие сети центров «Мой бизнес». Если в 2019 году таких центров насчитывалось 20, то к 2024 году планируется открыть 100 подобных центров. Немалую роль в популяризации предпринимательства сыграют комплексные программы по выявлению предпринимательских способностей граждан, поддержка сообществ начинающих предпринимателей, развитие института наставничества.

Важной задачей развития МСП является вовлечение новичков в предпринимательскую деятельность. Отлично зарекомендовала себя платформа «Бизнес-навигатор», которая помогает открыть своё дело начинающему предпринимателю. В ноябре 2019 года осуществлена интеграция Портала Бизнеснавигатора МСП с государственной информационной системой промышленности ГИСП[]. Это должно умножить возможности МСП в осуществлении производственной деятельности и организации сбыта продукции.

В результате перечисленных мер у граждан РФ должна сформироваться позитивная мотивация в отношении предпринимательской деятельности.

Особый акцент должен быть сделан на целевую группу российских граждан не старше 30 лет.

Молодежь во все времена являлась проводником новых идей. Данная социальнодемографическая группа в силу возрастных особенностей наиболее восприимчива к нововведениям и сама является генератором инноваций. Привлечение как можно большего числа молодежи к предпринимательской деятельности, тем не менее, наталкивается на ряд трудностей. Эти трудности носят скорее эмоциональный характер: боюсь не справиться, слишком сложно, слишком большой риск. Да, предпринимательская деятельность требует от человека умения брать на себя большую ответственность при неопределенности последствий от принятых решений, умения брать на себя риски. Играет свою роль и неосведомленность молодёжи в вопросах ведения производственного бизнеса.

Так по результатам опроса студентов 4 курса по направлению подготовки «Организация работы с молодёжью» ГУРФиКС сложилась следующая картина.

Учащимся было предложено задание: изучить платформу Бизнес-навигатор и на её основе организовать малое предприятие. Из студенческой группы численностью 18 человек 17 студентов выбрали предприятия в сфере услуг. Один студент выбрал сферу торговли. И ни один из студентов даже не рассматривал возможности организовать малое предприятие в сфере производства.

Согласно паспорту нацпроекта «МПС и поддержка индивидуальной предпринимательской инициативы» к 2024 году основам ведения бизнеса и финансовой грамотности должны будут обучены 450 тысяч человек, в том числе из целевой группы лиц до 30 лет[2]. Возрастёт роль технопарков, которые планируется организовывать в регионах. Такие промышленные парки будут финансировать с целью:

- реконструкции производственных и офисных зданий; инженерных сетей;

централизованного подключения

- закупки промышленного оборудования коллективного пользования.

Планируется формирование единой цифровой среды, обеспечивающей эффективное взаимодействие, как с органами государственной власти, так и партнёрами-смежниками и 
потребителями конечного промышленного продукта.

Такие меры имущественной поддержки позволят МСП увеличить объём инвестиций в основной капитал и создать качественно новые производства. Косвенно это создает большую привлекательность для молодёжи предпринимательства в сфере производства. А поскольку планируется увеличение МСП, прежде всего, в сфере производства и доведение доли таких предприятий до 69 процентов из общего числа МСП, необходимо привлечение большего внимания молодёжи к организации подобных предприятий.

\section{Список литературы:}

1.Основы ГМП в РФ на период до 2025 года. Распоряжение Правительства от 29 ноября 2014 г. N 2403-p.

2.Паспорт национального проекта «Малое и среднее предпринимательство и поддержка индивидуальной предпринимательской инициативы»// www.government.ru/info/35563.

3.Послание Президента Федеральному Собранию от 20.02.2019. «Послание Президента Федеральному Собранию».//www.consultant.ru 